\title{
Imago Dei: We are but dust and shadow
}

\begin{tabular}{|c|c|}
\hline \multicolumn{2}{|c|}{$\begin{array}{l}\text { Authors: } \\
\text { Annelien C. Rabie-Boshoff }{ }^{1,2} \\
\text { Johan Buitendag }\end{array}$} \\
\hline \multicolumn{2}{|c|}{$\begin{array}{l}\text { Affiliations: } \\
{ }^{1} \text { Department of Systematic } \\
\text { Theology, Cape Town Baptist } \\
\text { Seminary (CTBS), Cape Town, } \\
\text { South Africa }\end{array}$} \\
\hline \multicolumn{2}{|c|}{$\begin{array}{l}{ }^{2} \text { Department of Systematic } \\
\text { and Historical Theology, } \\
\text { Faculty of Theology and } \\
\text { Religion, University of } \\
\text { Pretoria, Pretoria, } \\
\text { South Africa }\end{array}$} \\
\hline \multicolumn{2}{|c|}{$\begin{array}{l}\text { Research Project Registration: } \\
\text { Project Leader: J. Buitendag } ₫ \\
\text { Project Number: } 2402343\end{array}$} \\
\hline \multicolumn{2}{|c|}{$\begin{array}{l}\text { 'Understanding Reality } \\
\text { (Theology and Nature)', } \\
\text { directed by Prof. Dr Johan } \\
\text { Buitendag, Department of } \\
\text { Systematic and Historical } \\
\text { Theology, Faculty of Theology } \\
\text { and Religion, University of } \\
\text { Pretoria. }\end{array}$} \\
\hline \multicolumn{2}{|c|}{$\begin{array}{l}\text { Corresponding author: } \\
\text { Johan Buitendag, } \\
\text { johan.buitendag@tuks.co.za }\end{array}$} \\
\hline $\begin{array}{l}\text { Dates: } \\
\text { Received: } 20 \\
\text { Accepted: } 31 \\
\text { Published: } 12\end{array}$ & $\begin{array}{l}\text { Apr. } 2021 \\
\text { May } 2021 \\
\text { Aug. } 2021\end{array}$ \\
\hline \multicolumn{2}{|c|}{$\begin{array}{l}\text { How to cite this article: } \\
\text { Rabie-Boshoff, A.C. \& } \\
\text { Buitendag, J., 2021, 'Imago } \\
\text { Dei: We are but dust and } \\
\text { shadow', HTS Teologiese } \\
\text { Studies/Theological Studies } \\
\text { 77(3), a6766. https://doi.org/ } \\
\text { 10.4102/hts.v77i3.6766 }\end{array}$} \\
\hline \multicolumn{2}{|c|}{$\begin{array}{l}\text { Copyright: } \\
\text { (c) 2021. The Authors. } \\
\text { Licensee: AOSIS. This work } \\
\text { is licensed under the } \\
\text { Creative Commons } \\
\text { Attribution License. }\end{array}$} \\
\hline \multicolumn{2}{|l|}{ Read online: } \\
\hline 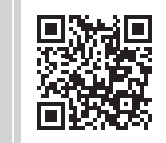 & $\begin{array}{l}\text { Scan this QR } \\
\text { code with your } \\
\text { smart phone or } \\
\text { mobile device } \\
\text { to read online. }\end{array}$ \\
\hline
\end{tabular}

This article is about the imago Dei, proceeding from an ecotheological perspective. Both the 'image of God' and the 'likeness of God' are examined based on the understanding that God is a relational God. It approaches the question of the imago Dei in terms of God's incorporeal nature, and what it is that human beings have in common with God apart from the human being's capacity for personal and interpersonal relationships. It addresses the question of the imago Dei in terms of God's spiritual nature and the human being's 'earthly' nature by utilising the metaphor of 'shadow'. This metaphor was investigated in terms of its meaning in Hebrew (tselem), and Genesis 2:7-8 where the creation of the human being is described in terms of God breathing the breath of life into the human being. A distinction has been drawn between the 'image of God' and the 'likeness of God', with the 'likeness of God' (demuth) that was investigated in the context of Exodus 31:1-5, and the various spiritual gifts conferred to Bezalel by the Spirit of God. Based on this investigation the article posits that the imago Dei as the Shadow of God (life) has been bestowed on all living creatures and not only human beings.

Contribution: The suggestion that the imago Dei as the Shadow of God is present in all of the creation urges us to seek further and look deeper into the issue of imago Dei in the sense that such an understanding pointedly has far-reaching implications for the current understanding of the place of human beings in creation. In consideration of this, it bears on our understanding of the meaning of life within the bigger picture of creation and how we respond to the living environment with which we share life.

Keywords: image; likeness; relationality; ecotheology; life; unique; resemblance; incorporeal; communion; shadow.

\section{Introduction}

The cornerstone of theological anthropology, which is of prime importance to understanding human personhood, is the imago Dei. This concept is a foundational doctrine of both Judaism and Christianity and even of Sufism, ${ }^{1}$ which presents some idea of the image of God. Notwithstanding all the interest having been afforded to the phrase, '[...] in the image of God, [...] in our likeness' (Gn 1:26-27), throughout the long history of theology (Peterson 1999:283-306), Clines (1968:53) had highlighted the 'brevity and scarcity' of this doctrine, pointing out that there are only three brief passages in Genesis referring to it: Genesis 1:26, 5:2 and 9:6. In reference to Vriezen ${ }^{2}$ (1943:87-105, especially p. 87), Clines observes that: '[...] the importance of the doctrine is out of all proportion to the laconic treatment it receives in the Old Testament' (see Williams 2011:315). Clines' observation is affirmed by Moltmann's (1985:215) statement that: '[...] the biblical traditions do not offer any justification for the central place given to this concept'. The volume of research is so overwhelming that Welz (2011:74) commented that to catch up with the history of the theme of imago Dei in the span of a few pages is an impossible task with the researcher running the risk of missing out on some crucial texts dealing with the theme. ${ }^{3}$ Simango (2016:172), like Welz, in his treatise of the history of the interpretation of the imago Dei, called for further attention to the large volume of material and broadness of the subject with special reference to the current theology and science discourse, which makes it difficult to deal with the topic in only one article, and which necessitates authors to work selectively.

A distinct golden thread seemingly holds together the numerous interpretations of the imago Dei, a persistent search for one or more features exclusive to the human being, which could be

1.Refer article by David Cashin, The Image of God and the Oneness of God, for a brief discussion on the mystic Islamic movement of Sufism (https://www.ciu.edu/content/image-god-and-oneness-god-0), and M.S. Adly's book, Taweed or Sufism (2003).

2.See T.C. Vriezen, 1943, OTS 2: 87-105, especially p. 87.

3.Van Huyssteen (2006:111-162) has offered us a brave attempt in his exposition.

Note: The authors would like to acknowledge Horatius: 'Pulvis et umbra sumus - We are but dust and shadow' (David Ferry, trans., 1997:18). Note: Special Collection: Theology and Nature, sub-edited by Johan Buitendag (University of Pretoria). 
said to distinguish the human being as a unique creature amongst many in creation. Leidenhag (2017:255), in her excursus on human uniqueness and the imago Dei, stated that: 'The imago Dei is the concept which Christian theologians continue to use most frequently in order to articulate human uniqueness'. At large, Christian theologians typically have endeavoured in identifying one or more superior qualities in human beings that constitute the imago Dei and which may support the notion of human uniqueness. Salient qualities that purportedly affirm the uniqueness of the human being in creation include, amongst others, human consciousness, human free will, human rationality, a substantial soul, objective morality and intrinsic value (Bentley 2017:n.p.; Cortez 2010:14-40; Moreland 2009:1-210; Van Huyssteen 2006:126-145). Other qualities such as human identity (Betschart 2019:268; Peterson 2016:53-83), human perfection (Cochran 2009:402415) and more (see Cortez 2010:16-17; De Smedt \& De Cruz 2014:135-156) have also been identified and are said to differentiate human beings from the rest of creation. Apart from these distinctive qualities, descriptive models have been developed that serve as valuable tools to classify each quality. Welz (2011:74-91), for one, had selectively identified four models ${ }^{4}$ of interpretation and used influential texts in explaining each model (Welz 2011:76-85; see Brunner, Butler \& Swoboda 2014:122; Simango 2016:178-184), one of these being the relational model, which is of interest to this article regarding the theology and science discourse.

Besides accusing feminist theologians, Leidenhag (2017:255) also held those in dialogue with the natural sciences and ecotheologians responsible for, what she calls, problematising human uniqueness as a: 'defining hook of theological anthropology'. She contends that: 'As a result of these penetrating critiques, the imago Dei [struggles] under constant redefinition and ambiguity'. One finds it surprising that Daniel Brunner ${ }^{5}$ and his colleagues (2014:122) commented from an ecotheological perspective that: 'At the heart of theological anthropology is what it means to be created in the image of God, imago Dei'.

\section{Methodology}

This article proceeds aright from an ecotheological perspective and examines both the 'image of God' (imago Dei; Gn' 1:26-28; 'image' - tselem), and 'the likeness of God' ('likeness' - demuth) in a relational context based on relevant literature. Rabie-Boshoff (2016:345) found in her PhD study that the DSL Model, ${ }^{7}$ which was developed as a heuristic tool for Genesis 1 and now applied to the imago Dei, has

4.(1) The functional model emphasising representation, (2) the mimetic model
emphasising resemblance, (3) the relational model emphasising the event of being addressed and (4) the dynamic model emphasising (con)formation.

5.Note: Daniel L. Brunner, professor of Christian History and Formation at George Fox Evangelical Seminary, and co-author of the book, Introducing Evangelical Ecotheology: Foundations in Scripture, Theology, History, and Praxis (2014) must be who will be referred to in this article by the name, Emil Brunner.

6.Unless otherwise stated, all Scripture references are taken from The Holy Bible, New International Version, Revised August 1983, November 1986, Bible Society of South Africa.

7.DSL: Divine Sign Language.
'[...] resulted in the surprising discovery of an underlying relational ${ }^{8}$ structure to the created world', which can be discerned from the first creation story. This finding affirms the understanding that God as Creator exists in relationship with God's entire creation, more significantly so with human beings (Rabie-Boshoff 2016:346). Like most contemporary theologians, the Early Church Fathers held varying views of God's image and the likeness of God. Whilst some of the Church Fathers viewed them as separate concepts, others did not distinguish between them (Burghardt 1961:147-160; Edwards 2006:15; Simango 2016:173-176). This necessarily raises the question of whether tselem and demuth refer to the same idea. RabieBoshoff concludes that the DSL Model: '[...] might provide a surprising understanding of these two concepts, and what is meant by humankind having been created "in the image of God"', a topic worth pursuing in the context of relationality because there is nothing in the context of Genesis 1:26-27, which indicates what tselem and demuth might mean. These two terms, however, clearly play a pivotal role in Genesis 1, as Brown (2017:312-313) indicated: 'On the one hand, the human body matters in Gen 1, given the language of "likeness" and "image"'. 'On the other hand', he says: 'human capacity over and against creation is highly valued', which is not the case in Genesis 2 and 3.

The imago Dei will be explored in the following manner - in the first instance, the metaphor of 'shadow' ${ }^{9}$ will be utilised to clarify the imago Dei, and in the second instance in the context of Genesis 2:7 where human beings are described as living beings (emphasis added). Both the terms, tselem and demuth will also be explored in an effort to ascertain whether there is any distinction between the ideas they relay. Tselem will be investigated in the context of Genesis 2:7, whilst demuth will be explored in the context of Exodus 31:3-5 (see Ex 35:31). ${ }^{10}$ The Exodus is the primary ground for the acting God and the Sabbath the primary ground for the presence of God.

\section{Relationality Unique creatures}

Moltmann (1985:185-186), dealing with the human being as a creature in the history of creation, called attention to philosophical and theological anthropology's starting point of human beings' uniqueness in terms of their differentiation from animals and their perceived '[...] special position in the cosmos'. This is illustrated by the fact that historically Jewish rabbis wrestled with the same question, asking why human beings are biblically presented: '[...] as the telos of creation' (Schwartz 2002:98). For Schwartz, in his perception of human

8.Notable theologians like Barth (1961), Moltmann (1985), Fretheim (2005) and Williams (2013) have developed relational theologies of creation based on sound hermeneutical principles.

9.Philo of Alexandria entertained a similar idea, albeit in a somewhat different context, believing that: 'the logos is only God's shadow, His image, the instrument by which He created the world, or in a more anthropomorphic way, His "first-born son" or His deputy' (https://plato/stanford.edu/entries/philo/).

10.For this analytical approach, see the very illuminating research of William P. Brown (2017). 
worth having been granted: '... through being created in the image of God', human beings as the 'telos of creation' should be considered as special guests: 'for [whom] everything had been created'.

In doing so he draws attention to Psalm 8:5, which speaks of God having created human beings 'a little lower than the heavenly beings' and bestowed them with glory and honour. Jewish scholars Saadiah Gaon (see Linetsky 2002 ${ }^{11}$; Stern 2019:n.p.) and Philo of Alexandria' ${ }^{12}$ echo this idea in their argument that the phrase, the 'image of God', is figurative language used to confer the idea of God having bestowed special honour on human beings. About Egyptian royal theology and the idea that the Pharaoh: '[...] is the reigning copy of God on earth, his representative, his deputy, his reflection and his mode of appearance in the world', Moltmann (1985:219) affirmed that Psalm 8: '[...] also presents the human being who has been created to be the image of God', as a 'royal personage'.

In contrast to the view of human worthiness as the centralising principle by which human uniqueness should be understood, human uniqueness finds expression in Barth's idea (1960:184-185) of the imago Dei, which involves the 'confrontation and reciprocity' (difference and relation) of an ' $\mathrm{I}$ ' and 'thou'. In this paradigm, God is the 'archetype and example', whilst the human being is the 'copy and imitation' (Welz 2011:81). Barth sees the image of God being expressed both vertically (between God and human being) and horizontally (between human beings) and concludes that God has created human beings to enter into a fellowship with God-self and with other human beings. In this sense, he excludes the rest of creation from this relationship with God. Barth (2004) contended:

It is not palpable that we have to do with a clear and simple correspondence, an analogia relationis, between this mark of the divine being, namely, that it includes an I and a Thou, and the being of man, male and female. (p. 196)

Like Barth, Westermann (1987:157-158) also viewed human uniqueness as an interactive relationship at work between God and human beings, explaining that God has created human beings for God to have a relationship with them - in his words: 'humans are created in such a way that their very existence is intended to be their relationship to God'. Westermann understands the imago Dei in the sense of a personal engagement between God and human being, which God initiates (Westermann 1974:58).

Whilst relationality is pertinent to the discussion of the imago Dei (See also Bonhoeffer 2004:62-63; Brunner 2002:1-128) and in light of the various arguments in favour of relationality as the centralizing principle for human uniqueness, it is evident

11.The book, Rabbi Saadiah Gaon's Commentary on the Book of Creation, annotated and translated by Michael Linetsky (2002:1-232), 'presents a translation into English of Rabbi Saadiah's commentary on a significant portion of the "Book of Genesis"' (Amazon.com).

12.Philo called, '[...] the invisible and intelligible Divine Reason (Logos) the Image of God' (Mead 1906:232, accessed at https://www.sacred-texts.com/gno/th1// th111.htm; also see https://plato.stanford.edu/entries/plato) that relationality does not tender human beings unique before God considering relationality being a characteristic of the entire creation, including human beings. ${ }^{13}$ And this is precisely the dilemma, which scholars face when dealing with the imago Dei-the question of what it is that differentiates human beings from other creatures in terms of a presupposed uniqueness. In this regard, Hoekema's (1986) struggle is evident when he pertinently asked:

Must we think of the image of God in man as involving only what man is and not what he does, or only what he does and not what he is, or both what he is and what he does? Is 'image of God' only a description of the way in which the human being functions, or is it also a description of the kind of being he or she is? (p. 69)

Unmistakably, research on human uniqueness has contributed much to the debate on the imago Dei. It is evident, however, that no characteristic has yet been identified that points to human beings as being unique and different from animals. In this regard, Wegter-McNelly (2011:22) commented on what he calls a self-deception of human uniqueness, writing that: 'The autonomous, self-constituting person, the much-vaunted "I" of the enlightenment, seems now to have had its day'. Long before, however, Moltmann $(1985: 187-188,190)$ already deviated from the idea of human uniqueness, adamant in his belief that the question should never be considered of what makes human beings different or unique, but rather what does human beings have in common with their shared environment. ${ }^{14}$ He does, however, affirm the portrayal of human beings as: '[...] the apex of created things', but dismisses the idea that they are: '[...] the crown of creation'. Instead, he draws out the point that the human being is a member of the: '[...] fellowship of creation' based on the fact that the biblical text reveals the human being as: ' $[\ldots]$ the earthly creature, [...] one creature among others' (Moltmann 1985:186-187). Humanity is clearly connected both to God and to the earth (see Brown 2017:153).

\section{Deviation in conceptualisation}

Overshadowing relationality, the pivotal issue at hand is that God is an invisible Spirit (Gn 1:2). Following suite, this research also deviates from the idea of human uniqueness. Instead, it addresses the question of the imago Dei in terms of God's spiritual nature (see Brown 2017:32-33) and the 'earthly' nature of human beings. ${ }^{15}$ Early in the Church's history Philo of Alexandria proposed the idea that: '[...] because God is a spiritual, non-material ${ }^{16}$ being, to be created

13.See Van Huyssteen (2006) par excellence on this topic. The following citation of Labuschagne (1996:131) says it all: '[T]he idea that there is a fundamental difference between human beings and animals is seriously questioned by the Speaker in the book of Ecclesiastes, whose merit was that he questioned and challenged the theological axioms of his time. [...] This covenant is anything but anthropocentric - it is clearly ecocentric' (Labuschagne 1996:131).

14.See Buitendag's article for an in-depth discourse on Jürgen Moltmann's 'ecotheological legacy': You must love the earth as yourself (2019:312).

15.Brown (2017:38) explained the term, 'groundling' or 'earthling' aptly.

16.There were those who believed that the resemblance between God and human being was physical in nature - see, amongst others, Maimonides: A.D. 1138-1204 (https://plato.standford.edu/entries/maimonides/), Gunkel (1964:112), Clines (1968:56), Middleton (1994:11), Migliore (2004:140). 
in his image and according to his likeness must refer to an immaterial, spiritual correspondence' (McDowell 2015:29; see Ex 20:1-4; Dt 4:15-16). In order, then, to engage the question of the imago Dei within a relational context, the question is not primarily why human beings should be seen as worthy or even as unique in the bigger scheme of things. In respect to God's incorporeal nature, the more favourable question would be instead to ask what human beings share with God apart from the commonalities they share with their environment given the fact that God resolved to make humans in God's image and God's likeness (Gn 1:26-27). From this, the question naturally follows in what way the human being could possibly resemble or represent the image and the likeness of the incorporeal God.

Having identified relationality as an attribute of God, of human beings and of creation at large appears to be restrictive to a certain extent in explaining the imago Dei. Nevertheless, bearing in mind that relationality, in essence, does not constitute the imago Dei, we are of the opinion that it does play a central role in the elucidation of the imago Dei. Hence, on these accounts, it is thus proposed that the imago Dei in essence, is an emergent property of relationality, in other words, an expression of relationship. In consideration of this proposition, and of the fact that Mosaic Law prohibited any physical representation of God (Ex 20:1, 2, 4; Dt 4:16; Migliore 2004:140) and the LCL principle ${ }^{17}$ (see Marmodoro ${ }^{18}$ 2015:94-110), the idea is posited that humans beings, having been created as imago Dei, exist in such an intimate relationship with God in a manner corresponding to the relationship between human beings and their shadow (immaterial). For this reason, the metaphor of 'shadow'19 has been appropriated to resolve the concept of imago Dei.

\section{The shadow of God: tselem}

The Hebrew word for 'image', according to Strong's \#6754, is âֶ and is derived from a shorter Hebrew word, tzel, meaning 'shadow' (Strong 2005:120; cf. Psalm 39:5-6; ESV). Tselem means 'to shade', a 'phantom' (see Ps 73:20; ESV), an 'illusion', a 'resemblance' or a 'representative figure'. Strong described 'image' as merely a 'phantom', representing the original but lacking the essential characteristics of that represented. Analogous to this explanation, the same could thus be said of one's own shadow - it is merely a 'phantom', an 'illusion' of oneself; it is in fact 'empty' and does not contain the fullness of one's own being. One fascinating example of applying this term in the Bible is found in the name 'Bezalel' (Gn 31:1), which literally means: 'in the shadow of God' (under God's protection).

Strong unfolds the concept further by explaining that when God created humanity, God created them as God's 'shade', in

17.LCL principle: Like causes like - a prominent idea that prevailed in ancient Greek thought.

18.Anna Marmodoro (2015) took on the complicated task of analysing Gregory of Nyssa's (c. 335-c. 395) struggle with the LCL principle and the idea of divine creation.

19.Science as a discipline has a considerable amount of insight to offer on the subject of 'shadow' - see Danezis (2005:11-17) and Economou (1994). other words, God's 'shadow'. ${ }^{20}$ When Karl Barth (2004) discussed the reality of 'Nothingness' in his Church Dogmatics (11l/3), he effectively applies the notion of 'shadow' in its derived ontological meaning:

What we have called the 'shadow side' of creation is constituted by the 'not' which in this twofold respect, as its distinction from God and its individual distinctiveness, pertains to creaturely nature. (p. 350)

This insight supports the conclusion that the 'qualities' of the shadow can be described in the same terms as that which Gregory of Nyssa used - it does occupy a three-dimensional volume of space and has both static and dynamic features: it is an incorporeal, abstract, intangible, yet intelligible shape and has no form or recognisable features, which represent God.

\section{A living being: nephesh chayyah}

God's close interaction with the human being is described in the second creation story (Gn 2:4-25), when God creates the human being from the dust of the earth (Gn 2:7). Whilst the first part of Genesis 2:7 focusses on creating the physical human body, the second part denotes something different. A profound interplay between God and human being is depicted when God brings the human being to life: '[...] and [God] breathed into his nostrils the breath of life, and the [hu]man became a living being' (Gn 2:7 - NIV; 'a living soul' - NLT; Hebrew: nephesh chayyah). Farris (2017) commented that:

Humans are not simply created, but humans are created and fashioned after something, namely God. First, it seems to me [he says], very natural that this is with respect to God's creation of a thing as a 'whatness'. (p. 112)

The answer to this 'whatness' is evident - being described as a living soul, the human being, as Moltmann (1985:187) explained, is: '[...] an animated body, not that he is a soul that has taken on flesh, $[\ldots]^{\prime}$. It is thus, within this relationship, which God establishes with the human being that life emerges. This life is manifested in the physical creation, first and foremost in and through the human body which, so to speak, has been taken from the earth. Relationship and life are both abstract entities, immaterial and incorporeal in nature. However, they are intelligible entities, meaning that they can be fully described by definitions (see Marmodoro 2015:109). Thus, it is posited that life emerging from the relationship with God could be referred to as the "The Shadow of God', in other words, the imago Dei. ${ }^{21}$

For Farris (2017:109), the concept of the imago Dei also points to some immaterial quality, which in his

20.Apart from the biblical concept of shadow, the idea also appears in the ancient Egyptian and Persian contexts, but it is about concrete forms. For the Egyptian context refer Moltmann (1985:219) and Isaiah 30:2. For the ancient Zoroastrian (Persian) context refer Met Museum (Cuirass (Chair-aina): 17th - early 18th (Persian) context refer Met Museum (Cuirass (Chair-aina): 17th - early 18th century; https://www.metmuseum.org/art/collection/search/24007), Ben (History of Iran: The origin and development of imperialist contention in Iran; www.iranchamber.com/history/articles/origin_development imperialist contention_iran2.php) and Niaz (2017; The Shadow of God, https://islamicus.org/ shadow-of-god//

21.This agrees with Maimonides' (ed. Levin 2019:133) idea that tselem denotes something 'incorporeal'. 
understanding is the soul (see Calvin 1536:165), and which he terms 'a property bearer' (image-bearer). In the context of 'The Shadow of God', the physical body of the human being now becomes the image-bearer of the imago Dei. As a consequence of God's relationship with the entire creation, the whole of creation could thus be said to be the image-bearer of the imago Dei. This inference may be problematic to Moltmann's view that human beings are: '[...] God's one and only image' (1985:186, 190). However, his words would thus ring true that we should first talk about the human being theologically as: '[...] a creature in the fellowship of creation'. And he continues that:

[...] before we interpret this being as imago Dei, we shall see him as imago [societatis et] mundi - as a microcosm in which all previous creatures are to be found again, a being that can only exist in community with all other created beings and which can only understand itself in that community. (p. 186)

\section{The likeness of God: Demuth}

The 'likeness of God' is more often than not included in a discussion of the imago Dei, with no distinction being made between the two phrases. According to Strong, however, there is a marked difference between tselem and demuth (תדוּ). Demuth (Strong's \#1823; Strong 2005:32) is derived from damah, denoting a resemblance of someone or something in action or appearance (see Ps 58:4; Is 13:4; Ezk 23:15), or 'to be like' (conceptually alike, or of the same type), and not 'to look like' or it could denote an abstract relation - a distinction consisting in a property, which no other living creatures possess, for example, some intellectual property.

In an effort to gain clarity concerning the question of similarity between the two concepts, Genesis 2:7 and Exodus 31:1-5 are being put together with the connecting factor being '[...] the breath of life' (Gn 2:7) and '[...] the Spirit of God' (Ex 31:3; Heb: ruah êlohim). According to Hamilton (2011:521), this is only the third time that the phrase, ruah elohim, is used apart from Genesis 1:2 and 41:38. This in itself is extraordinary as Bezalel is the first person mentioned in the Bible whom the Lord 'filled' with the Spirit of God, but more so in the sense that he is an ordinary workman and not some outstanding gifted individual.

In Exodus 31:3-5, four spiritual gifts are listed, which were conferred to Bezalel when the Spirit of God came upon him: wisdom, understanding (insight), knowledge and the ability to perform one or more tasks (artistry) - gifts that have not been conferred to any other non-human creature. Durham's (1987:410) explanation shed some light on the nature of these gifts: Bezalel, having been filled with the Spirit of God was equipped with these gifts that '[...] adds to his native ability $[\ldots]$ ': wisdom - '[...] the gift to understand what is needed to fulfil Yahweh's instructions', understanding (insight) - '[...] the talent for solving the inevitable problems' involved in the project at hand and skill - '[...] the experienced hand to guide and accomplish the labour itself'.
It is evident that special gifts or qualities are conferred to human beings to perform particular tasks sanctioned by God to specifically fulfil God's purposes (Ware 2002:79) - in Bezalel's case to oversee the building of the Temple according to a specific plan provided by God. In Genesis 1:26-27, the salient point is made that God created human beings in God's image (the Shadow of God; imago Dei) and in God's likeness, that is to say then, endowed with wisdom, understanding, knowledge and an ability to perform work. In Genesis 1:28, God's creation purposes for human beings are revealed in terms of them having been given the tasks to be fruitful and increase in number, to fill the earth and subdue it and to rule over all the living creatures. According to Rushdoony (2004:457), these gifts are God-ordained and '[...] an aspect of our calling, so that God is more involved in our skills than we are'. This underscores the proposition that human skills and abilities (the likeness of God) are bound up with the life-giving breath of God, as is the imago Dei.

\section{Tselem and/or demuth?}

In spite of claims that tselem and demuth convey different perspectives on the imago Dei, most scholars are of the opinion that a careful study of passages such as Genesis 1:26-27, 5:1-3 and 9:6 reveals that these two words do not refer two diverse concepts, reaching the conclusion that 'likeness' simply emphasises the imago Dei. Athanasius (c. 293-373 AD), for example, did not distinguish between tselem and demuth. He believed that the imago Dei became obscured because of the Fall, to be restored in Christ. Burghardt (1961) summarised:

Like his Alexandrian predecessors, Athanasius excludes the corporeal from man's imaging. Unlike them, the concept of a progression from image to likeness is absent from his perspectives. In his view, perfection was given at the outset; man's task is to recapture it. And in this process it is the ontological that concerns him, it is being rather than appearance that is of interest to him; in a word, participation. (p. 152)

Dyrness' (1972:162) observation that: '[T]he two words should be seen as having complementary rather than competing meanings' supports the foregoing distinction between tselem and demuth. He sheds light on his own understanding by explaining that: 'The first stresses it being shaped and the second it being like the original in significant ways'. In contrast, Feinberg (1972:237) remarked that it is impossible to avoid the conclusion that the two words are not referring to the same concept but concludes that they are used interchangeable, an insight that we do not underscore. More in line with the views presented herein, Hoekema's (1986:13) clear argument against a differentiation is justifiable when he writes that: 'If these words were intended to describe different aspects of the human being, they would not be used, that is, almost interchangeably'.

The Eastern Orthodox Church and the medieval Western Church clearly distinguished between the two phrases (Cortez 2010:116). Feinberg (1972:237) mentioned that some of the Early Church Fathers suggested that the two concepts should be distinguished from each other, teaching that 
tselem referred to the physical aspects, whilst demuth referred to the ethical part of the divine image. Irenaeus, for example, held the view that 'image' referred to humans' unchangeable essence, in other words their freedom and rationality, whilst 'likeness' referred to the changing part of humans - their relationship with God. In contrast, Origen, believed that the 'image' of God was given to humankind at creation, whilst the 'likeness' of God was bestowed on humankind at a later time.

In reference to Moltmann's statement that human beings are: 'God's one and only image', it could now be suggested that the interpretation, 'the likeness of God', instead would fully agree with Moltmann's idea, but in a re-worded format. In other words, the suggestion is that it could instead be re-stated to mean: 'human beings are God's one and only likeness', born from the understanding that wisdom, experience, knowledge and the ability to work have exclusively been conferred on human beings and not to animals. The two words' relation is like a terminus a quo and a terminus ad quem, a starting point and a final point. Moltmann prefers subsequently the preposition created to the image of God and not merely in the image of God. Christology fulfils anthropology. The social Trinity sets the paradigm that human beings become imago Christi and creation imago societatis et mundi.

\section{Findings}

The principal obstacle that underpins this debate is the very question that shapes the debate, which is that if God has created all living creatures including human beings and has caused them to come alive through God's breath of life, why then are human beings supposedly unique compared to all other living creatures and what is it particularly that makes human beings unique. Undoubtedly, the imago Dei is the primary driving force behind this debate. To date, scholars have tried their best to identify a particularly characteristic feature in human beings that accounts for their uniqueness as imago Dei. However, it has been a struggle, and as a result, several models have been developed to deal with the issue. As a foundational concept and doctrine of Christianity, the imago Dei has contributed a great deal to the debate on what it means to be human, a debate that is still continuing at this point in time.

One of the themes around the imago Dei that has been identified, and the model that has consequently been developed is that of relationality, the argument being that human beings have the capacity for interpersonal relationship and social interaction, both with God and fellow human beings, and with all creation. Evidence suggests that the relationship per se is not adequate to explain the imago Dei. In the context of the question that was asked, it came to the fore that the property emerging from the relationship between God and human beings, and creation as a whole, is the property of life, interpreted as the Shadow of God embodied in the human person and also represented in a multitude of other forms in creation.
Moltmann (1985:219) held to the view that: '[a]s his image, human beings represent God on earth', believing that tselem and demuth are descriptive of a special status designated to human beings, whereas we contend that these terms do not refer to a special status, but rather that both are attributes that tselem is an attribute that is represented outward (the whole of creation), whilst demuth is an inward reflective attribute (human beings only). The Shadow of God, just like the physical human person, has a history of a past and a present, but unlike the human body, which is subject to death, the idea of the 'Shadow of God' as 'life' points to the future and beyond. The dynamic view of which Migliore is the foremost proponent, seems to be the most promising to use in explicating the imago Dei, more so, according to Welz (2011:83), in terms of Giovanni Pico della Mirandola's work. This view evokes the idea that the imago Dei is not to be found in the structure, relationships and functions of being human. Rather, it should be understood as a goal towards which redeemed humanity is moving - as Migliore (2004:147) verbalised it: 'Being created in the image of God is not a state or condition but a movement with a goal: human beings are restless for a fulfilment of life not yet realised'.

The fact that the biblical text highlights human creation in such a way that could be interpreted as human beings being unique creatures in their relationship with God, and God being the life-giver of human beings, does not tender human beings unique in creation because the ancient Hebrew mind understood humans and animals (not plants) as sharing alike in life (cf. Gn 9:5). This life in human beings, however, is undeniably very important judged against the story of Cain. He murdered his brother Abel (Gn 4) and the later prohibition given to Moses in Exodus 20:13. The presence of this lifesharing quality present in all living creation urges one to seek further and look deeper into this issue as the interpretation of the imago Dei as the Shadow of God, life itself, may have farreaching implications in the current understanding of the place of human beings in creation and the meaning of life within the bigger picture of creation and how we as human beings should respond to the living environment with which we share life. The distinction made between tselem and demuth, and the proposed idea that the imago Dei points to life as a representative image of God are foreseen to be of significant value in an ecotheological context given the pathological destruction of the earth and the mindless, power-driven utilisation of earth's resources to the fulfilment of human beings' desires.

Let us use a citation from Moltmann to convey this truth:

The Jewish-Christian symbol of man as the image in the visible world of the invisible God must also be newly interpreted today, in view of man's wealth of power and potentiality, if it is to be an effective symbol of his responsibility for the control of evolution in nature and his genetic experiments on himself. (Loc. 1888-1890)

The seminal ideas proposed in this study will lend themselves to shedding more light on the question of whether the 
concepts of imago Dei and the likeness of God are plausible for an ecotheology and for what it means to be human.

\section{Acknowledgements Competing interests}

The authors declare that they have no financial or personal relationships that may have inappropriately influenced them in writing this article.

\section{Authors' contributions}

A.C.R.-B. conceptualised the idea based on her dissertation and drafted the initial manuscript. J.B. refined it and developed the reference of the theology and science discourse.

\section{Ethical considerations}

This article followed all ethical standards for research without direct contact with human or animal subjects.

\section{Funding information}

This research received no specific grant from any funding agency in the public, commercial or not-for-profit sectors.

\section{Data availability}

Data sharing is not applicable to this article as no new data were created or analysed in this study.

\section{Disclaimer}

The views and opinions expressed in this article are those of the authors and do not necessarily reflect the official policy or position of any affiliated agency of the authors.

\section{References}

Adly, M.S., 2003, Taweed or Sufism, Al-Adly Publications, Columbia, SC.

Barth, K., 1960, Church dogmatics, Volume 3: The doctrine of Creation Part 1, eds. G.W. Bromiley \& T.F. Torrance, T\&T Clark, Edinburgh.

Barth, K., 2004, Church dogmatics, Volume 3: The doctrine of creation, Part 3, eds. G.W. Bromiley \& T.F. Torrance, T\&T Clark, London.

Benab, Y.P., n.d., History of Iran: The origin and development of imperialist contention in Iran; 1884-2021, Iran Chamber Society, viewed 21 January 2021, from www. iranchamber.com/history/articles/origin_development_imperialist_contention iran2.php.

Bentley, W., 2017, 'Are we special? A critique of imago Dei', HTS Teologiese Studies/ Theological Studies 73(3), 4524. https://doi.org/10.4102/hts.v73i3.4524

Betschart, C., 2019, 'Review of PhD dissertation by Peterson, R.S., 2016, 'The Imago Dei as Human Identity: A Theological Interpretation' (Journal of Theological Interpretation Supplements 14, Eisenbrauns, ISBN 978-1-57506-433-8)', Teresianum 70(1), 268-271.

Bonhoeffer, D., 2004, Creation and fall, ed. J.W. De Gruchy, transl. D.S. Bax, Fortress Press, Minneapolis, MN.

Brown, W.P., 2017, A handbook to Old Testament exegesis, Presbyterian Publishing Corporation, Louisville, KY.

Brunner, D.L., Butler, J.L. \& Swoboda, A.J., 2014, Introducing evangelical ecotheology: Foundations in scripture, theology, history and praxis, Baker Academic, Grand Rapids, MI.

Brunner, E., 2002, 'Nature and grace', in E. Brunner \& K. Barth (eds.), Natural theology, pp. 15-64, Wipf \& Stock, Eugene, OR.

Buitendag, J., 2009, 'Nature as creation from an eco-hermeneutical perspective: From a "natural theology" to a "theology of nature"', HTS Teologiese Studies/ Theological Studies 65(1), Art. \#272, 1-10. https://doi.org/10.4102/hts.v65i1.272
Buitendag, J., 2019, 'Jy moet die aarde liefhê soos jouself' (Eng: You must love the earth as yourself)', LitNet Akademies 16(3), 305-320.

Burghardt, W.J., 1961, 'The image of God in man: Alexandrian orientations', Ejournals, viewed 29 March 2021, from https://ejournals.bc.edu/ojs/index.php/ ctsa/article/download/2521/2142.

Calvin, J., 1536, The Institutes of the Christian Religion, transl. H. Beveridge, 1845, Christian Classics Ethereal Library, Grand Rapids, MI, viewed 20 March 2021, from https://www.ccel.org/ccel/c/calvin/institutes/cache/institutes.pdf.

Cashin, D., n.d., The image of God and the Oneness of God, viewed 11 March 2021 from https://www.ciu.edu/content/image-god-and-oneness-god-0.

Clines, D.J.A., 1968, 'The image of God in man', Tyndale Bulletin 19, 53-103.

Cochran, E.A., 2009, 'The imago Dei and human perfection: The significance of Christology for Gregory of Nyssa's understanding of the human person', The Heythrop Journal 50(3), 402-415. https://doi.org/10.1111/j.1468-2265. 2009.00459.x

Cortez, M., 2010, Theological anthropology: A guide for the perplexed, T\&T Clark, London.

Danezis, E., Theodosiou, E., Gonidakis, I. \& Dimitrijevic, M.S., 2005, “'Un-tangible world" and modern physics', European Journal of Science and Theology 1(4), $11-17$

De Smedt, J. \& De Cruz, H., 2014, 'The imago Dei as a work in progress: A perspective from Paleoanthropology', 'Zygon 49(1), 135-156. https://doi.org/10.1111/ zygo.12066

Durham, J.I., 1987, Word biblical commentary, Volume 3: Exodus, Word Books, Publisher, Waco, TX.

Dyrness, W.A., 1972, 'The imago Dei and Christian aesthetics', Journal of the Evangelical Society 15(3), 161-172.

Economou, E., 1994, Theological ecology, Mavromates, Athens, GA.

Edwards, D., 2006, Ecology at the heart of faith: The change of heart that leads to a new way of living on the earth, Orbis Books: Maryknoll, New York, NY.

Farris, J.R., 2017, 'An immaterial substance view: Imago Dei in creation and redemption', The Heythrop Journal LVIII 58(1), 108-123. https://doi.org/10.1111/ jeyj.12274

Feinberg, C.L., 1972, 'Image of God', Bibliotheca Sacra 129/515, 235-246, July-September. Ferry, D. (transl.), 1997, The Odes of Horace, by Horatius, The University of Chicago Press, Chicago, IL.

Fretheim, T.E., 2005, God and the World in the Old Testament: A relational theology of creation, Abingdon Press, Nashville, TN.

Gunkel, H., 1964, Genesis, Vandenhoeck und Ruprecht, Göttingen.

Hamilton, V.P., 2011, Exodus: An exegetical commentary, Baker Academic, Grand Rapids, MI.

Hoekema, A.A., 1986, Created in God's image, Eerdmans, Grand Rapids, MI.

Labuschagne, C.J., 1996, 'Creation and the status of humanity in the Bible', in V. Brümmer (ed.), Interpreting the universe as creation, pp. 123-131, Kok Pharos, Kampen.

Leidenhag, J., 2017, 'Uniqueness and the presence of the image: Towards a pneumatological foundation for human uniqueness and the image of God', in M. Fuller, D. Evers, A. Runehov \& K.W. Saether (eds.), Issues in science and religion: Are we special? Issues in science and religion: Publications of the European Society for the Study of Science and Theology, vol. 4, pp. 255-270, Cham. https://doi. org/10.1007/978-3-319-62124-1_19

Levin, N. (ed.), 2019, 'Maimonides and Jewish Philosophy', in Philosophy of Western religions: An open educational resource, pp. 131-137, N.G.E. Far Press, viewed 20 March 2021, from https://www.ngefarpress.com/2019/05/philosophy-ofwestern-religions-open.html.

Linetsky, M., 2002, Rabbi Saadiah Gaon's Commentary on the Book of Creation, Jason Aronson Inc. Publishers, Lanham, MD.

Marmodoro, A., 2015, 'Gregory of Nyssa on the Creation of the World', in B.D. Prince \& A. Marmodoro (eds.), Causation and creation in late antiquity, pp. 94-110, Cambridge University Press, London.

McDowell, C.L., 2015, The Image of God in the Garden of Eden: The creation of humanity in Genesis 2:5-3:24 in Light of the mis pî pit pî and wpt-r Rituals of Mesopotamia and Ancient Egypt, Eisenbrauns, Winona Lake.

Mead, G.R.S., 1906, Philo of Alexandria and Hellenistic Theology, viewed 15 March 2021, from https://www.sacred-texts.com/gno/th1/th111.htm.

Met Museum, n.d., Cuirass (Chair-aina): 17th - Early 18th century, viewed 21 January 2021, from https://www.metmuseum.org/art/collection/ search/24007.

Middleton, J.R., 1994, 'The liberating image? Interpreting the Imago Dei in Context', Christian Scholars Review 24(1), 8-25.

Migliore, D.L., 2004, Faith seeking understanding: An introduction to Christian Theology, 2nd edn., William B. Eerdmans, Grand Rapids, MI.

Moltmann, J., 1985, God in creation: A new Theology of creation and the spirit of God, The Gifford Lectures 1984-1985 (Translated by Margaret Kohl from the German, Gott in der Schöpfung: Ökologische Schöpfungslehre, 1985, Münich: Christian Kaiser Verlag), Fortress Press, Minneapolis, MN.

Moreland, J.P., 2009, The recalcitrant Imago Dei: Human persons and the failure of naturalism, SCM Press, London.

Niaz, A., 2017, The shadow of God, viewed 21 January 2021, from https://islamicus. org/shadow-of-god/.

Peterson, G.R., 1999, 'The evolution of consciousness and the Theology of Nature', Zygon 34(2), 283-306. https://doi.org/10.1111/0591-2385.00213 
Peterson, R., 2016, The Imago Dei as Human Identity, (see Chapter 3, p. 53-83), Eisenbrauns, Winona Lake.

Rabie-Boshoff, A.C., 2016, Seeing God's voice in creation; A visio-spatial interpretation of Genesis 1, Unpublished PhD thesis, University of Pretoria, viewed 16 January 2021, from http://hdl.handle.net/2263/61551.

Rushdoony, R.J., 2004, Commentaries on the Pentateuch: Exodus, Ross House Books, Vallecito, CA.

Schwartz, E., 2002, 'Mastery and stewardship, wonder and connectedness: A typology of relations to nature in Jewish Text and Tradition', in H. Tirosh-Samuelson (ed.), Judaism and Ecology: Created world and revealed World, pp. 93-106, Harvard University Press, Cambridge, MA.

Simango, D., 2016, 'The Imago Dei (Genesis 1:26-27): A history of interpretation from Philo to the Present', Studia Historiae Ecclesiasticae 42(1), 172-190. https://doi. org/10.25159/2412-4265/1065

Stern, G., 2019, Re-imagining God and Man for a New Year, viewed 14 March 2021 from https://madlik.com/tag/imagio-dei/.

Strong, J., 2005,' New Strong's Concise Dictionary of the Words in the Hebrew Bible with their Renderings in the King James Version', pp. 1-101 (C 1995 Thomas Nelson Publishers, Inc.), in New Strong's exhaustive concordance: King James Version, pp. 1-1640, Thomas Nelson, Inc., Nashville, TN.
Van Huyssteen, J.W., 2006, Alone in the World? Human uniqueness in science and Theology, William B Eerdmans Publishing Company, Grand Rapids, MI.

Vriezen, T.C., 1943, 'La création de I'homme d'après l'image de Dieu' (Eng: 'The creation of man after the image of God'), OTS 2, 87-105.

Ware, B., 2002, 'Male and female complementarity and the image of God', in W. Grudem (ed.), Biblical foundations for Manhood and Womanhood, pp. 71-92, Crossway, Wheaton, IL.

Wegter-McNelly, K., 2011, The entangled God: Divine relationality and quantum physics, Routledge, New York, NY.

Welz, C., 2011, 'Imago Dei: References to the invisible', Studia Theologica 65(1), 74-91. https://doi.org/10.1080/0039338X.2011.578372

Westermann, C., 1974, Creation, Fortress, Philadelphia, PA.

Westermann, C., 1987, Genesis 1-11: A commentary, Augsburg Publishing House, Minneapolis, MN

Williams, D.T., 2011, “"He is the image and glory of God, but women..." (1 Cor 11:7): Unveiling the understanding of the imago Dei', Scriptura 108, 314-325. https:// doi.org/10.7833/108-0-5

Williams, D.T., 2013, ULUNTU, a relational theology of humanity, Cluster Publications, Pietermaritzburg. 